\title{
Minat Membaca dan Implementasinya dalam Bimbingan dan Konseling
}

Marimbun ${ }^{1}$

${ }^{1}$ Program Studi Bimbingan dan Konseling Islam IAIN Langsa

${ }^{1}$ marimbun@iainlangsa.ac.id

$\begin{array}{ccc}\text { First received: } & \text { Revised: } & \text { Final Accepted: } \\ 11 \text { November 2019 } & \text { 05 December 2019 } & \text { 09 December 2019 }\end{array}$

\begin{abstract}
Reading interst is a strong desire that accompanied a sense of pleasure of enjoyment of reading with self-will. Reading is a demand for individuals because reading is an effective activity to gain insight and knowledge. Surah Al-Alaq which is the first letter to come down is a reading order. Furthermore, the mandate of regulations and legislation also invites reading culture and encourages people to enjoy reading. The problematics of some of the research results indicate that Indonesian interest in reading is still relatively low. Therefore how important are efforts to foster interest in reading. Improving interest in reading must be done through families, education units and the community. One of the factors influencing reading interest is the teacher. Counseling teacher/ Counselor is a teacher assigned to carry out guidance and counseling activities in schools responsible for providing various service activities in developing various student potentials and encouraging national education goals. Guidance counseling at schools is expected to be more intensive in order to improve students interest in reading through various types of counseling services. As for some services that can be applied in improving interest in reading such as orientation services, information, group guidance and individual counseling.
\end{abstract}

Keywords: Reading interest, Guidance and Counseling

\begin{abstract}
Abstrak
Minat membaca merupakan keinginan yang kuat yang disertai rasa senang untuk memahami bacaan dengan kemauan diri sendiri. Membaca merupakan tuntutan kepada individu karena membaca merupakan aktivitas yang efektif untuk memperoleh wawasan dan ilmu pengetahuan. Surat Al-Alaq yang merupakan surat yang pertama kali turun adalah perintah membaca. Selanjutnya, amanat peraturan dan perundang-undangan juga mengajak untuk membudayakan membaca dan mendorong masyarakat untuk gemar dalam membaca. Problematika dari beberapa hasil penelitian menunjukkkan minat membaca orang Indonesia masih tergolong rendah. Oleh karena itu betapa pentingnya upaya-upaya untuk menumbuhkan minat membaca. Meningkatkan minat membaca harus dilakukan melalui keluarga, satuan pendidikan dan masyarakat. Salah satu faktor yang mempengaruhi minat membaca adalah guru. Guru BK/Konselor adalah guru yang ditugaskan untuk melaksanakan kegiatan bimbingan dan konseling di sekolah bertanggungjawab untuk memberikan berbagai kegiatan layanan dalam mengembangkan berbagai potensi siswa serta mendorong tujuan pendidikan nasional. Pelayanan BK di sekolah diharapkan lebih intensif guna meningkatkan minat membaca siswa melalui berbagai jenis layanan BK. Adapun beberapa layanan yang dapat diterapkan dalam meningkatkan minat membaca seperti layanan orientasi, informasi, bimbingan kelompok dan konseling perorangan.
\end{abstract}

Kata Kunci: Minat Membaca, Bimbingan dan Konseling

\section{PENDAHULUAN}

Surah Al-Alaq merupakan surah yang pertama kali diturunkan Allah SWT kepada Nabi Muhammad SAW. Didalamnya banyak mutiara ilmu yang menakjubkan. salahsatunya faidah yang terdapat dalam surah tersebut adalah perintah membaca (Shihab, 2009)

Bacalah dengan (menyebut) nama Tuhanmu Yang menciptakan, Dia telah menciptakan manusia dari segumpal darah, Bacalah, dan Tuhanmulah Yang Maha Pemurah, Yang mengajar 
(manusia) dengan perantaran kalam, Dia mengajar kepada manusia apa yang tidak diketahuinya (Q.s Surat Al-Alaq:1-5)

Membaca merupakan proses yang dilakukan individu untuk memperoleh pesan yang disampaikan oleh penulis melalui media. Menurut Kamus Besar Bahasa Indonesia (2005: 83), membaca adalah melihat serta memahami isi dari apa yang tertulis. Undang-undang Nomor 20 Tahun 2003 tentang Sistem Pendidikan Nasional pasal 4 ayat 5 dinyatakan bahwa "prinsip penyelenggaraan pendidikan adalah dengan mengembangkan budaya membaca, menulis, dan berhitung bagi segenap warga masyarakat". Undangundang Nomor 43 Tahun 2007 tentang Perpustakaan pasal 48 ayat 1 dinyatakan bahwa "pembudayaan kegemaran membaca dilakukan melalui keluarga, satuan pendidikan dan masyarakat". Selanjutnya, Kementerian Pendidikan dan Kebudayaan (Kemendikbud) telah menerbitkan Peraturan Menteri Pendidikan dan Kebudayaan (Permendikbud) Nomor 23 Tahun 2015 tentang Penumbuhan Budi Pekerti melalui pembiasaan membaca selama 15 menit sebelum belajar. Menindaklanjuti amanat peraturan perundang-undangan tersebut Kemendikbud melalui Badan Pengembangan Bahasa dan Perbukuan terus berupaya untuk meningkatkan pengadaan buku bacaan di sekolah dan komunitas. Senada dengan itu, UndangUndang Nomor 3 tahun 2017 tentang Sistem Perbukuan pada pasal 11 ayat 2 memberikan dukungan terhadap terciptanya masyarakat belajar, masyarakat gemar membaca, dan masyarakat gemar menulis. Pada pasal 4 butir c, bahwa tujuan penyelenggaraan sistem perbukuan adalah untuk menumbuhkembangkan budaya literasi seluruh Warga Negara Indonesia.

Dari penjelasan di atas, merupakan tuntutan kepada individu untuk gemar membaca karena dengan membaca merupakan aktivitas yang efektif untuk memperoleh wawasan dan ilmu pengetahuan. Kegiatan membaca seharusnya menjadi budaya terutama untuk memperoleh pengetahuan dan wawasan yang luas. Oleh karena itu, Agama, UU, dan peraturan mengamanatkan untuk membaca dan mendorong tumbuhnya minat atau pembudayaan kegemaran membaca. Bangsa yang memiliki kualitas membaca rendah akan mengalami keterbelakangan dan ketertinggalan (Maharani, 2017). Oleh karena itu, betapa pentingnya menumbuhkan minat membaca. Menurut Syah (2006), minat (interest) berarti kecenderungan dan kegairahan yang tinggi atau keinginan yang besar terhadap sesuatu. Namun dari beberapa hasil penelitian mengungkapkan bahwa minat membaca orang Indonesia masih tergolong rendah. Hasil penelitian Program for International Student Assessment (PISA) rilisan Organisation for Economic CoOperation and Develompent (OECD) tahun 2015 menunjukkan rendahnya tingkat literasi Indonesia dibanding negara-negara di dunia. Dari hasil penelitian terhadap 72 negara, Indonesia berada pada ranking 62 (detiknews, Januari 2019). Studi yang dilakukan Central 
Connecticut State University tahun 2016 mengenai Most Literate Nations in The World menjelaskan bahwa minat membaca masyarakat Indonesia hanya sebesar 0,01 persen atau satu berbanding sepuluh ribu.(Suara.com Februari 2018).

Dari beberapa hasil penelitian di atas, menunjukkkan minat membaca orang Indonesia masih tergolong rendah. Oleh karena itu, betapa pentingnya upayaupaya untuk menumbuhkan minat membaca. Perlu adanya kerjasama untuk meningkatkan minat membaca, mulai dari keluarga, satuan pendidikan, dan masyarakat.

\section{PEMBAHASAN}

\section{Pengertian Minat Membaca}

Menurut Kamus Besar Bahasa Indonesia (2005: 83), membaca adalah melihat serta memahami isi dari apa yang tertulis. Membaca merupakan suatu proses yang dilakukan oleh pembaca untuk memperoleh pesan yang hendak disampaikan penulis melalui media katakata/bahasa tulis. Sedangkan minat membaca merupakan dorongan untuk memahami kata demi kata dan isi yang terkandung dalam teks bacaan tersebut, sehingga pembaca dapat memahami halhal yang dituangkan dalam bacaan. Minat membaca merupakan aktivitas yang dilakukan dengan penuh ketekunan dalam rangka membangun pola komunikasi dengan diri sendiri untuk menemukan makna tulisan dan menemukan informasi mengembangkan intelektualitas yang dilakukan dengan penuh kesadaran dan perasaan senang yang timbul dari dalam dirinya. (Dalman, 2014: 5)

Menurut Slameto (2003:180), minat adalah rasa suka dan rasa keterikatan pada suatu hal atau aktivitas, tanpa ada yang menyuruh. Farida Rahim (2005: 28), mengemukakan bahwa minat membaca adalah keinginan yang kuat disertai dengan usaha-usaha individu untuk membaca. Senada dengan itu, Menurut Wahadaniah (1997), minat membaca adalah suatu perhatian yang kuat dan mendalam disertai dengan perasaan senang terhadap kegiatan membaca sehingga dapat mengarahkan individu untuk membaca dengan kemauannya sendiri atau dorongan dari luar. Dari beberapa pengertian di atas, dapat disimpulkan bahwa minat membaca adalah keinginan yang kuat yang disertai rasa senang untuk memahami bacaan dengan kemauan diri sendiri.

\section{Faktor-faktor yang Mempengaruhi Minat Membaca}

Harris dan Sipay (1980), mengemukakan bahwa minat membaca dipengaruhi oleh dua golongan, yaitu golongan faktor personal dan golongan institusional. Faktor personal meliputi: (1) usia, (2) jenis kelamin, (3) intelegensi, (4) kemampuan membaca, (5) sikap, (6) kebutuhan psikologis. Sedangkan faktor institusional meliputi: (1) tersedianya buku-buku, (2) status sosial ekonomi, (3) pengaruh orang tua, teman sebaya dan guru. 
Dawson dan Bamman dalam (Rachman, 1985: 6) mengemukakan beberapa faktor yang mempengaruhi minat baca yaitu sebagai berikut:

1. Tujuan dan manfaat yang diperoleh setelah membaca, yaitu rasa aman, status dan kedudukan tertentu, kepuasan afektif dan kebebasan yang sesuai dengan kenyataan serta tingkat perkembanagan siswa, kebutuhan itu berpengaruh pada pilihan dan minat baca masing-masing individu.

2. Tersedianya sarana buku bacaan keluarga merupakan salah satu pendorong terhadap pilihan bacaan dan minat baca siswa dan kemungkinan bahwa minat baca juga didorong oleh status sosial ekonomi keluarga.

3. Guru berperan dalam menumbuhkan minat membaca setiap individu karena dengan informasi yang menarik tentang sebuah buku, maka siswa akan tertarik untuk membacanya dan sekaligus memperoleh sumber informasi.

4. Tersedianya sarana dan prasarana perpustakaan, jumlah dan ragam bacaan yang disenangi akan meningkatkan minat baca.

5. Faktor jenis kelamin juga berfungsi sebagai pendorong perwujudan pemilihan buku bacaan dan minat baca murid.

6. Saran-saran teman sekelas sebagai faktor eksternal dapat mendorong timbulnya minat baca murid.

\section{Upaya Meningkatkan Minat Membaca}

Minat membaca mempunyai pengaruh yang besar terhadap kemajuan suatu bangsa. Dibandingkan dengan beberapa negara tetangga, minat baca masyarakat Indonesia masih termasuk rendah. Minat baca menjadi kunci penting bagi kemajuan suatu bangsa, karena penguasaan Iptek hanya dapat diraih dengan minat membaca yang tinggi. Aspek keluarga, masyarakat, dan lembaga pendidikan mempunyai peran penting dalam meningkatkan minat baca masyarakat. Upaya meningkatkan minat membaca anak menjadi tanggungjawab bersama, antara pustakawan, guru, orang tua, dan masyarakat. Guru mempunyai tanggung jawab langsung dalam meningkatkan minat membaca. Dalam upaya meningkatkan minat membaca seharusnya dimulai dari sejak dini, sebaiknya anak-anak diberi stimulan agar minat baca itu muncul dari diri murid itu sendiri (Kasiyun, 2015).

Ada beberapa cara menumbuhkan minat baca menurut Hasyim dalam (Dalman, 2014: 146- 148). yaitu berikut ini: (1) mengenalkan bacaan sejak dini, (2) Dorongan anak bercerita tentang apa yang telah didengar atau dibacanya, (3) ajak anak ke toko buku/perpustakaan, (4) beli buku yang menarik minat anak, (5) sisihkan uang untuk membeli buku, (6) nonton film dan beli bukunya, (7) ciptakan perpustakaan keluarga, (8) tukar buku dengan teman, (9) hilangkan penghambat seperti televisi atau playstation, (10) beri hadiah (reward) yang memperbesar semangat membaca, (11) jadikan buku sebagai hadiah (reward) untuk anak, (12) jadikan kegitan bacaan sebagai kegitan setiap hari, (13) dramatisi buku yang anda 
baca, (14) peningkatan minat baca, (15) memiliki kesadaran dan minat yang tinggi terhadap membaca, (16) menyediakan waktu membaca.

Berdasarkan keterangan di atas minat baca seorang anak bergantung dengan kreativitas orang tuanya dalam menumbuhkan minat membaca pada anaknya, tentu hal ini dilakukan dengan bebagai cara yang harus ditempuh. Orangtua yang memiliki waktu yang banyak dalam memperhatikan anakanaknya ketika di rumah untuk menjadikan aktivitas anak selalu berkaitan dengan membaca sehingga minat dalam diri anak dapat ditimbuhkan.

Kreativitas dan inisiatif tenaga pendidik di sekolah sangat penting dalam rangka meningkatkan minat membaca. Menurut Saleh (2006, 45-46)Beberapa kegiatan yang dianjurkan adalah: (1) agar guru pustakawan menerbitkan daftar buku anak-anak, (2) mengundang pustakawan dan para guru agar bekerjasama dalam merencanakan kegiatan promosi minat baca, (3) mengorganisasi lomba minat baca di sekolah, (4) memilih siswa teladan yang telah membaca buku terbanyak, (5) melaksanakan program wajib baca di sekolah, (6) menjalin kerjasama antar perpustakaan sekolah, (7) memberikan tugas baca setiap minggu dan melaporkan hasil bacaannya, (8) menceritakan orangorang yang sukses sebagai hasil membaca, (9) menugaskan siswa untuk membuat abstrak dari buku-buku yang dibaca, (10) menugaskan siswa belajar ke perpustakaan apabila guru tidak hadir, (11) menerbitkan majalah/buletin sekolah, (12) mengajarkan teknik membaca kepada siswa,

memberikan waktu khusus kepada siswa untuk membaca, (13) menyelenggarakan pameran buku secara periodik, (14) dan lain-lain. Selain itu, Saleh (2006), mengungkapkan bahwa peran teknologi sangat diperlukan dalam meningkatkan minat membaca seperti buku dalam bentuk digital atau elektronik (e-book atau electronic book) yang dapat diperoleh baik melalui toko buku maupun melalui internet. Buku berbentuk elektronik banyak keistimewaan seperti: menghemat ruangan, (2) multiple akses, (3) tidak dibatasi oleh ruang dan waktu, (4) dapat berbentuk multimedia, (5) biaya lebih murah.

Dari penjelasan di atas, dapat disimpulkan perlunya kerjasama semua elemen dalam meningkatkan minat membaca, mulai dari keluarga, satuan pendidikan, peran teknologi dan masyarakat.

\section{Implementasinya dalam Bimbingan dan Konseling}

Guru BK/ Konselor adalah guru yang ditugaskan untuk melaksanakan kegiatan bimbingan dan konseling di sekolah. Undang-undang No 20 Tahun 2003 tentang Sistem Pendidikan Nasional, Pasal 1 ayat 1 menjelaskan bahwa: "pendidikan adalah usaha sadar dan terencana untuk mewujudkan suasana belajar dan proses pembelajaran agar peserta didik secara aktif mengembangkan potensi dirinya untuk memiliki kekuatan spiritual keagamaan, pengendalian diri, 
kepribadian, kecerdasan, akhlak mulia, serta keterampilan yang diperlukan dirinya, masyarakat, bangsa dan negara". Ayat 5 mencantumkan, "Pendidikan adalah tenaga kependidikan yang berkualifikasi sebagai guru, dosen, konselor, pamong belajar, widyaswara, tutor, instruktur, fasilitator, dan sebutan lain yang sesuai dengan kekhususannya, serta berpartisipasi dalam menyelenggarakan pendidikan".

Guru BK bertugas dan bertanggungjawab untuk memberikan berbagai kegiatan layanan dan kegiatan pendukung dalam mengembangkan berbagai potensi peserta didik serta mendorong tujuan pendidikan nasional. Pelayanan BK di sekolah diharapkan dapat meningkatkan minat membaca siswa dengan berbagai jenis layanan BK yang dapat diterapkan dengan lebih intensif guna meningkatkan minat membaca siswa. Adapun beberapa layanan yang dapat diterapkan dalam meningkatkan minat membaca antara lain adalah sebagai berikut:

\section{Layanan Orientasi}

Menurut Prayitno (2004, 255), layanan orientasi dilakukan untuk memperkenalkan siswa terhadap lingkungan yang baru dimasukinya. Layanan orientasi memungkinkan siswa memahami lingkungan seperti sekolah yang baru dimasukinya, dalam rangka mempermudah dan memperlancar berperannya siswa di lingkungan yang baru (Sukardi, 2000: 43). Layanan orientasi sangat diperlukan untuk memperkenalkan lingkungan sekolah kepada siswa baru, misalnya tentang program pengajaran, kegiatan ekstrakurikuler, aturan sekolah dan suasana pergaulan, cara-cara belajar yang baik, serta memperkenalkan fasilitas dan sumber belajar yang ada seperti ruang kelas, laboratorium, perpustakaan, dan ruang praktek. Salah satu tujuan dari layanan orientasi adalah memberikan pemahaman kepada siswa agar dapat pemahaman yang diperlukan bagi keberhasilan belajar di sekolah. Melalui layanan orientasi, Guru BK/Konselor dapat memberikan materi pengenalan perpustakaan, cara belajar yang efektif dengan memampaatkan perpustakaan sekolah yang mampu memberikan dorongan kepada siswa dalam meningkatkan minat membaca.

\section{Layanan Informasi}

Layanan informasi adalah kegiatan memberikan pemahaman kepada siswa tentang berbagai hal yang diperlukan untuk menentukan arah dan tujuan yang diharapkannya (Prayitno, 2004: 259). Layanan informasi merupakan layanan yang diselenggarakan Guru BK/Konselor kepada siswa yang bertujuan agar siswa memperoleh pemahaman berbagai materi untuk pengembangan potensi dirinya yang mengarahkan siswa mampu mencapai perkembangan dirinya. Informasi dapat dilakukan secara lisan, tertulis, media elektronik, media cetak dan lain-lain. Cara penyampaian biasa dilakukan dengan ceramah, tanya jawab dan diskusi, atau metode lainnya.

Menurut Tohirin (2007), layanan informasi bertujuan agar siswa memperoleh pengetahuan, penguasaan 
informasi yang dimanfaatkan untuk keperluan hidupnya sehari-hari dan perkembangan dirinya. Pelaksanaan layanan informasi ditujukan untuk membekali peserta untuk menambah wawasan, pengetahuan, keterampilan, nilai, dan sikap yang diperoleh siswa melalui Guru BK/ Konselor. Layanan ini dapat digunakan sebagai bahan acuan dalam meningkatkan minat membaca. Materi layanan yang akan diberikan adalah materi-materi yang dapat meningkatkan minat membaca yang disertai berbagai contoh nyata dari kondisi di lapangan. Adapun materi yang terkait dengan peningkatan minat membaca siswa ke arah yang lebih baik sebagai contoh Tips-tips meningkatkan minat membaca. Guru BK/ Konselor harus mampu menjadi motivator untuk mendorong terwujudnya minat membaca yang tinggi dan mengatur kegiatan membaca siswa serta memberikan petunjuk untuk menciptakan suasana psikologis yang kondusif demi terwujudnya jiwa, semangat dan motivasi dalam membaca yang optimal.

\section{Layanan Bimbingan Kelompok}

Bimbingan kelompok adalah kegiatan yang dilakukan oleh sekelompok orang dengan memanfaatkan dinamika kelompok. Artinya, semua peserta dalam kegiatan kelompok saling berinteraksi, bebas mengeluarkan pendapat, menanggapi, memberi saran, dan lain-lain sebagainya. Apa yang dibicarakan dalam bimbingan kelompok semuanya bermanfaat untuk diri peserta yang secara bersama-sama memperoleh berbagai bahan dari nara sumber yang berguna untuk menunjang kehidupannya sehar-hari (Prayitno, 2004). Layanan bimbingan kelompok yaitu layanan yang membantu siswa dalam pengembangan pribadi, kemampuan hubungan sosial, kegiatan belajar, karir/jabatan, dan pengambilan keputusan, serta melakukan kegiatan tertentu melalui dinamika kelompok.

Tujuan dari pelaksanaan layanan bimbingan kelompok adalah mendorong pengembangan pikiran, perasaan, sikap, tindakan dan tanggung jawab siswa dari suatu topik yang dibahas terkait dengan materi tentang meningkatkan minat membaca. Lebih lanjut, pelaksanaan layanan bimbingan kelompok bertujuan merangsang pemikiran kreatif siswa, mampu dan berani menyampaikan ide-ide sehingga di dalam proses perkembangannya siswa juga berani menyusun ide-idenya sendiri dan bertanya jika ada suatu hal yang kurang dipahaminya.

Guru BK/Konselor dapat melaksanakan kegiatan bimbingan kelompok topik tugas terkait meningkatkan minat membaca, sehingga pada akhirnya semua anggota kelompok bisa mengaktualisasikan dirinya di lingkungan sekolah. Menurut Prayitno (2004: 65) pelaksanaan kegiatan bimbingan kelompok ini dilakukan dalam empat tahap yaitu:

a. Tahap Pembentukan

Tahap pengenalan dan perlibatan dari anggota ke dalam kelompok dengan tujuan agar anggota memahami 
maksud bimbingan kelompok.

Pemahaman anggota kelompok memungkinkan anggota kelompok aktif berperan dalam kegiatan bimbingan kelompok yang selanjutnya dapat menumbuhkan minat pada diri mereka untuk mengikutinya. Pada tahap ini bertujuan untuk menumbuhkan suasana saling mengenal, percaya, menerima, dan membantu teman-teman yang ada dalam kelompok. Kegiatan yang dilakukan pada tahap ini adalah mengungkapkan pengertian dan tujuan kegiatan kelompok dalam rangka pelayanan bimbingan kelompok; menjelaskan cara-cara dan asas-kegiatan kelompok; anggota kelompok saling memperkenalkan diri dan mengungkapkan diri; dan melakukan permainan pengakraban.

b. Tahap peralihan

Tahap ini transisi dari tahap pembentukan ke tahap kegiatan. Dalam menjelaskan kegiatan apa yang akan dilaksanakan pemimpin kelompok dapat menegaskan jenis kegiatan bimbingan kelompok tugas atau bebas. Setelah jelas kegiatan apa yang harus dilakukan maka tidak akan muncul keragu-raguan atau belum siapnya anggota dalam melaksanakan kegiatan dan manfaat yang diperoleh setiap anggota kelompok. Tujuan dari tahap ini adalah terbebasnya anggota dari perasaan atau sikap enggan, ragu, malu, atau saling tidak percaya untuk memasuki tahap berikutnya; makin mantapnya suasana kelompok dan kebersamaan; makin mantapnya minat untuk ikut serta dalam kegiatan kelompok.

c. Tahap kegiatan

Tahap ini merupakan tahap inti dari kegiatan bimbingan kelompok dengan suasana yang ingin dicapai, yaitu terbahasanya secara tuntas permasalahan yang dihadapi oleh anggota kelompok dan terciptanya suasan untuk mengembangkan diri, baik yang menyangkut pengembangan kemampuan berkomunikasi maupun menyangkut pendapat yang dikemukakan oleh kelompok. Kegiatan yang dilakukan pada tahap ini untuk topik tugas adalah pemipin kelompok mengemukakan suatu topik untuk dibahas oleh kelompok; kemudian terjadi tanya jawab antara anggota dan pemimpin kelompok tentang hal-hal yang belum jelas menyangkut topik yang dikemukakan pemimpin kelompok. Selanjutnya anggota membahas topik tersebut secara mendalam dan tuntas, serta dilakukan kegiatan selingan bila diperlukan. Sedangkan untuk bimbingan kelompok topik bebas, kegiatan yang dilakukan adalah masing-masing anggota secara bebas mengemukakan topik bahasan; menetapkan topik yang akan dibahas dahulu; kemudian anggota membahas topik secara mendalam dan tuntas, serta diakhiri kegiatan selingan bila perlu.

d. Tahap pengakhiran

Pada tahap ini terdapat dua kegiatan yaitu penilaian dan tindak lanjut (follow up). Tahap ini merupakan tahap 
penutup dari serangkaian kegiatan bimbingan kelompok dengan tujuan telah tuntasnya topik yang dibahas oleh kelompok tersebut. Dalam kegiatan kelompok berpusat pada pembahasan dan penjelasan tentang kemampuan anggota kelompok untuk menetapkan hal-hal yang telah diperoleh melalui layanan bimbingan kelompok dalam kehidupan seharihari. Oleh karena itu pemimpin kelompok berperan untuk memberikan penguatan (reinforcement) terhadap hasil-hasil yang telah diapai oleh kelompok tersebut. Kegiatan yang dilakukan dalam tahap ini adalah pemimpin kelompok mengemukakan bahwa kegiatan akan segera diakhiri; pemimpin kelompok dan anggota kelompok mengemukakan kesan dan hasil-hasil kegiatan; membahas kegiatan lanjutan; kemudian mengemukakan pesan dan harapan.

\section{Layanan Konseling Perorangan}

Menurut Tohirin (2007: 296), konseling perorangan adalah pemberian bantuan yang dilakukan melalui hubungan yang bersifat face to face relationship (hubungan empat mata), yang dilaksanakan antara konselor dengan klien. Sementara itu, menurut Willis (2013: 159), konseling perorangan adalah pertemuan konselor dengan klien secara individual, dimana terjadi hubungan konseling yang bernuansa rapport, dan konselor berupaya memberikan bantuan

untuk pengembangan pribadi klien serta klien dapat mengantisipasi dalam masalah yang dihadapinya.
Layanan konseling perorangan adalah layanan yang diselenggarakan oleh guru $\mathrm{BK} /$ konselor terhadap klien secara langsung dengan cara bertatap muka, dalam rangka pengentasan masalah pribadi klien. Melalui layanan konseling perorangan, klien memahami seluk beluk masalah yang dialami secara mendalam, komprehensif, positif dan dinamis

\section{Dengan layanan konseling} perorangan beban klien diringankan, kemampuan klien ditingkatkan, dan potensi klien dikembangkan. Tujuan layanan konseling perorangan dalam hal ini terkait tentang meningkatkan minat membaca. Pelaksanaan layanan konseling perorangan terkait dalam meningkatkan minat membaca, layanan ini bersifat insidentil, namun demikian kegiatan ini juga dapat dilaksanakan dengan cara memanggil klien, yang diketahui atau terindikasi memiliki minat membaca yang rendah yang didasarkan pada hasil asessmen yang dilakukan oleh guru BK/Konselor atau pihak lainnya.

\section{SIMPULAN}

Dari beberapa hasil penelitian menunjukkan bahawa minat belajar masyarakat Indonesia masih tergolong rendah. Untuk meningkatkan minat belajar perlu partisipasi semua elemen, mulai dari keluarga, satuan pendidikan, dan masyarakat. Guru BK/ Konselor yang ditugaskan untuk melaksanakan kegiatan bimbingan dan konseling di sekolah dapat memberikan beberapa jenis layanan dalam meningkatkan minat belajar seperti, 
layanan orientasi, informasi, bimbingan kelompok, dan konseling perorangan.

\section{DAFTAR PUSTAKA}

Al-Quran Terjemahan.

(2015)

Departemen Agama RI. Bandung: CV

Darus Sunnah.

Abdul Rahman Saleh, 2006. Peranan Teknologi Informasi dalam Meningkatkan Kegemaran Membaca dan Menulis Masyarakat. Jurnal Pustakawan Indonesia. 6 (1). 46-49. https://docplayer.info $>47180885$

Peranan-teknologi-in

Dalman. (2014). Keterampilan Membaca. Jakarta: Rajawali Pers

Danu, D. (2019). Benarkah Minat Belajar Orang Indonesia Serendah ini?. Detik News, Online, https://m.detik.com

Departemen Pendidikan Nasional. (2003). Undang-Undang Nomor 20 Tahun 2003, Tentang Sistem Pendidikan Nasional, Jakarta: Depdiknas.

Harris, A. J. Sipay, E.R. (1980). How To Increase Reading Ability: A Giude to Development and Remedial Methods: New York: Longman Inc.

Kasiyun. S. (2015). Upaya Meningkatkan Minat Baca Sebagai Sarana Untuk Mencerdaskan Bangsa. Jurnal Pena Indonesia. $1 \quad$ (1). 22477-5150. https://journal.unesa.ac.id/index.php/j pi/article/view/140

KBBI (Kamus Besar Bahasa Indonesia). (2005). Jakarta: PT Persero

Maharan. O. D. (2017). Minat Baca AnakAnak Di Kampoeng Baca Kabupaten
Jember. Jurnal Kajian Pendidikan dan

Hasil Penelitian. 3(1),2460-8475. https://journal.unesa.ac.id/index.php/P D.

Peraturan Menteri Pendidikan dan Kebudayaan (Permendikbud) Nomor 23 Tahun 2015

Rachman \& dkk. (1985). Minat Baca Murid SD Di Jawa Timur. Jakarta: Pusat Pembinaan dan Pengembangan Bahasa Depdikbud

Rahim, F. (2005). Pengajaran membaca di sekolah dasar. Jakarta: Bumi Aksara

Shihab, M. Q. (2009). Tafsir al-Misbah. Kairo: Lentera Hati.

Slameto. (2001). Evaluasi Pendidikan. Jakarta: Bumi Angkasa.

Sukardi, D. K. (2000). Pengantar Pelaksanaan Program Bimbingan dan Konseling di Sekolah. Jakarta:PT Rineka Cipta, 2000

Syah, M. (2006). Psikologi Pendidikan. Bandung: Remaja Rosdakarya.

Tohirin. (2007). Bimbingan Konseling di Sekolah dan Madrasah. Jakarta: Raja Grafindo Persada

Undang-Undang Nomor 3 tahun 2017 tentang Sistem Perbukuan

Undang-undang Nomor 43 Tahun 2007 tentang Perpustakaan.

Vania, R. (2018). Miris, Minat Baca Masyarakat Indonesia Hanya 0,01 Persen. Suara Com. Online, (http:www.suara.com.lifestyle)

Wahadaniah, H. (1997). Perpustakaan Sekolah sebagai Sarana Pengembangan Minat dan Kegemaran Membaca. Dalam Departemen Pendidikan dan Kebudayaan. Jakarta: 
Departemen Pendidikan dan

Kebudayaan.

Willis, S. (2013). Konseling Individual,

Teori dan Praktik. Bandung:Alfabeta

Winkel, W. S., \& Hastuti, M. S. (2005).

Bimbingan dan Konseling di Institusi

Pendidikan. Media Abadi. 